\title{
The Application of DLC Coating on Convex-concave (C-C) Gearings
}

Ernest Gondár ${ }^{1}$, Miroslav Bošanský², Juraj Rusnák ${ }^{3}$, František Tóth ${ }^{3}$, Jana Repková ${ }^{1}$

${ }^{1}$ Slovak University of Technology in Bratislava, Faculty of Mechanical Engineering, Institute of Technologies and Materials, Pionierska 15, 83102 Bratislava, Slovakia. E-mail: ernest.gondar@stuba.sk

${ }^{2}$ Slovak University of Technology in Bratislava, Faculty of Mechanical Engineering, Institute of Transport Technology and designing, Nám. slobody 17, 81231 Bratislava, Slovakia. E-mail: miroslav.bosansky@stuba.sk

${ }^{3}$ Slovak University of Agriculture in Nitra, Faculty of Engineering, Department of Machine design, Tr. A. Hlinku 2, 94976 Nitra, Slovakia

This paper discusses the possibility of increasing the surface load capacity in C60E steel gearings by applying DLC thin coating. It describes the effect of tribological characteristics, such as friction coefficient, wear, adhesion and hardness of DLC coating on convex-concave gearing (C-C). The average thickness of DLC coating is $1.2 \mu \mathrm{m}$. Delamination of the DLC coating was recorded at a load of approximately $50 \mathrm{~N}$. The friction coefficient of the DLC coating was 0.09. The nano-hardness of the DLC coating was $14.4 \mathrm{GPa}$. The results of the tests to scuffing on C-C gearings on the Niemann tester show that the DLC coating deposition occurred at load level 5. The complete removal of the coating was preceded by gradual thinning. After its removal, the wear continued substrate, where the traces after milling filled-up with the substrate metal.

Keywords: Convex-concave gearing, DLC, friction coefficient, Niemann's test

\section{Introduction}

Increasing the load capacity and durability of gearings is one of the problems that can be solved by design modification (changing tooth geometry), or technologically (using new materials or technologies). The design of gearings, or derivation of geometric dependence, is almost exclusively based on the "technological method", where the shape of the production tool, which is actually one member of the gearing, determines the correct mating flanks of the mating gear. At the same time, the gearing design must meet the requirements of the basic principle of gearing, where no production or operating interference is permitted. The design of gears is based on the specific requirements for gears. The mating teeth profile forming the shape constraint must be designed to allow continuous mesh in a constant gear ratio. For a specifically defined teeth profile of the pinion, a unique tooth profile of the mating flanks of the wheel is also determined, and, therefore also the shape of the path of contact. In the case of $\mathrm{C}-\mathrm{C}$ gearing, the path of contact is made up of circular arcs whose centre of curvature may have a different position relative to the central line. This means that, depending on the basic geometric parameters, it is possible to classify the individual types of planar gearings [1], as well as the shape of the tooth profile curve [2].

The theory behind the convex-concave gearing design is based on the mesh parameters (the lower the contact pressures, the lower the slip ratio, and the higher the contact load capacity, where the path of contact is composed of circular arcs $[1,2]$. The surface tooth load bearing capacity is affected by the magnitude of the contact pressures, as well as by the slip ratio. The comparison of involute and C-C gearings in terms of slip ratio is shown in Fig. 1. The C-C gearing has a significantly lower slip ratio in comparison with the involute gearing, especially on the pinion and wheel.

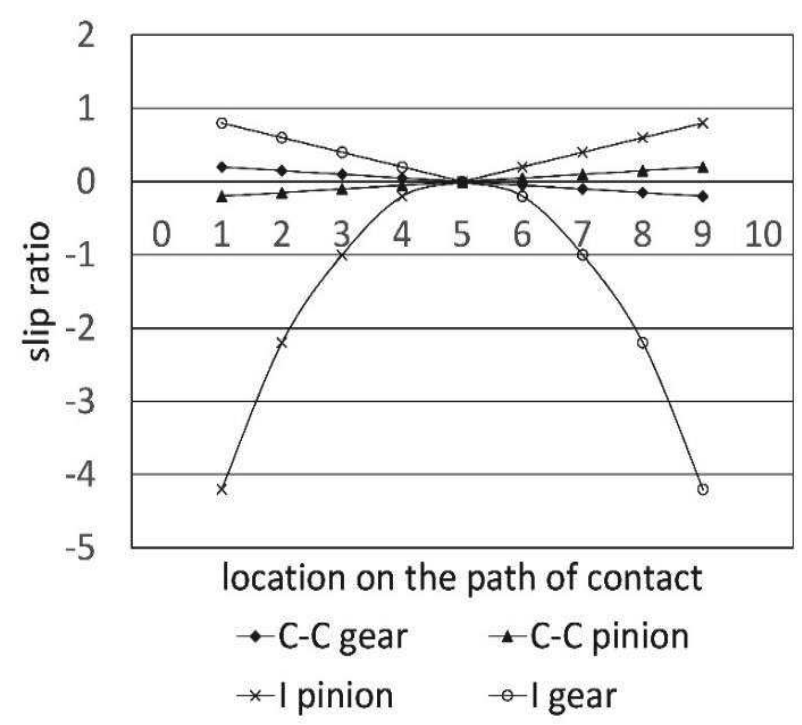

Fig. 1 The slip ratio convex-concave and involute gearing on the path of contact

The torque generates power contact in gearings, which involves high pressure values at the contact points between the tooth flanks. The magnitude of this pressure is an important indicator for the surface damage of the tooth flank and thus also for the life of gearings, so that it is important to know their size, or the radius of the tooth curvature at the contact point $\rho_{1,2}$. In the case of involute gearing, higher contact pressures are achieved, (the mesh of tooth flank is concave-concave - Fig. 2). In the C-C gearing, lower contact pressures are caused by the convex-concave mesh of the tooth, as shown in Fig. 3. Computational simulation of convex - concave and involute gearings from the point of view of contact pressures was made using ANSYS software. The contact pressure analysis shows that C-C gearing has $25 \%$ lower pressure in contact teeth than involute gearing. [3]. 


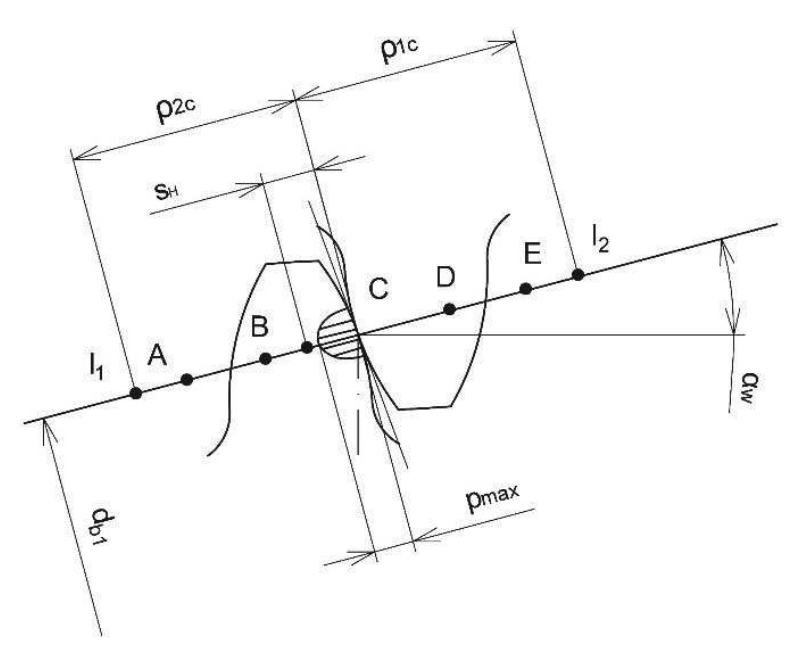

Fig. 2 Two teeth in mesh and contact pressure in involute gearing

The technological approach to increasing the load capacity of gearings includes various sophisticated technologies, including chemical and heat treatment methods [4]. The application of hard thin coatings on steel parts most often increases wear resistance [5] at higher temperatures [6], corrosion [7], as well as combined stress [8]. In particular, several technologies such as PVD, CVD, PACVD and others for the surface application of hard thin coatings have been used in the past few years with the development of material engineering to increase the load capacity of gearings. From previous experiments [9] it is clear that deposition of hard thin coatings on the surface of the tooth flank is one way of increasing load capacity, which also increases the load capacity of gearings for the required lifetime.

The present paper describes the properties of two surface coatings identified in laboratory conditions (Niemann's test) and their influence on the load capacity of $\mathrm{C}-\mathrm{C}$ gearing under operating conditions.

\section{Materials and methods}

Experimental samples and gears were made of $\mathrm{C} 60 \mathrm{E}$ (ASTM A576-B1) steel containing 0.57-065\% C, 0.5$08 \% \mathrm{Mn}$ and $0.15-0.4 \% \mathrm{Si}$. This steel is suitable for hardening and surface hardening. It is used to produce less loaded toothed gears, pins, spindles and machine parts with increased demands for abrasion resistance. When choosing DLC (Diamond Like Carbon) coating, we consider their application in gearings according to their different mechanical and tribological properties. The DLC designation is used for the metastable amorphous carbon state [10]. Although DLC coating have a graphite-like structure, they are characterized by lower hardness and abrasion resistance at low friction coefficients $(0.15)$ [11]. Nitrogen is used to improve adhesion to the substrate. The DLC was formed by PACVD technology and is a coating of: $\mathrm{C}-\mathrm{H}$ : $\mathrm{Si}$, the adhesive layer is $\mathrm{Cr}$, and DLC doped $\mathrm{Si}$ is deposited with plasma with $\mathrm{C}_{2} \mathrm{H}_{2}$.

On $30 \mathrm{~mm}$ diameter circular samples the thickness of the deposited coating and its chemical composition was determined by SEM and EDX analysis respectively. The adhesion of the coatings to the substrate was monitored by a scratch test [12] by means of a CSEM REVETEST test device. The scratch tests were carried out at a constant speed of the moving sample and at a constant increase in normal force from $1-100 \mathrm{~N}$. During the test, the acoustic emission signal dependence of the normal force was recorded. The influence of the coefficient of friction on normal force was also determined by this device. The nanohardness of the coatings was determined at $20 \mathrm{mN}, 2,5 \mathrm{mN}$ and $0,5 \mathrm{mN}$ loads. The depth of penetration of the Berkovich indentor into the sample was also observed.

Tribological evaluation of the thin coatings was performed on CSM Instrumental equipment by the Ball on Disk method. The counterpart was the $\mathrm{Al}_{2} \mathrm{O}_{3}$ ball. Tests were performed dry at $1 \mathrm{~N}$ load and a sample rate of 80 $\mathrm{mm} / \mathrm{s}$ on a $100 \mathrm{~m}$ track. The wear and friction coefficient were determined from the tribological characteristics. The wear was measured by the material weight loss and the friction coefficient from the frictional and normal force fraction.

Gear tests were performed on machined C-C teeth with roughness of about $1.1 \mu \mathrm{m}$. However, for the application of the coatings, the minimum roughness of the flank of the tooth is about $0.5 \mu \mathrm{m}$. Since the teeth are non-standard, special devices which were not available during the experiments, should be used to achieve the required roughness of the teeth. For this reason, the tested gears have to be run in soft state [13] to achieve the required roughness. Subsequently, the surface of the teeth was quenched by the laser and tempered at $450^{\circ} \mathrm{C}$ [14]. The objective was to obtain the desired surface hardness of the flank of the tooth (in substrate) preventing deformation of the deposited coating due to high contact pressures (Hertz's teeth pressures). The load capacity of the sealing coatings was determined by FZG test on Niemann's tester [15]. The wheels were tested under increasing load. The criterion for completing the test is to achieve a weight loss of 10 mg. The test gears were lubricated with the OMV Biogear S 150 ecological lubricant, which is suitable for use in agricultural machinery [16].

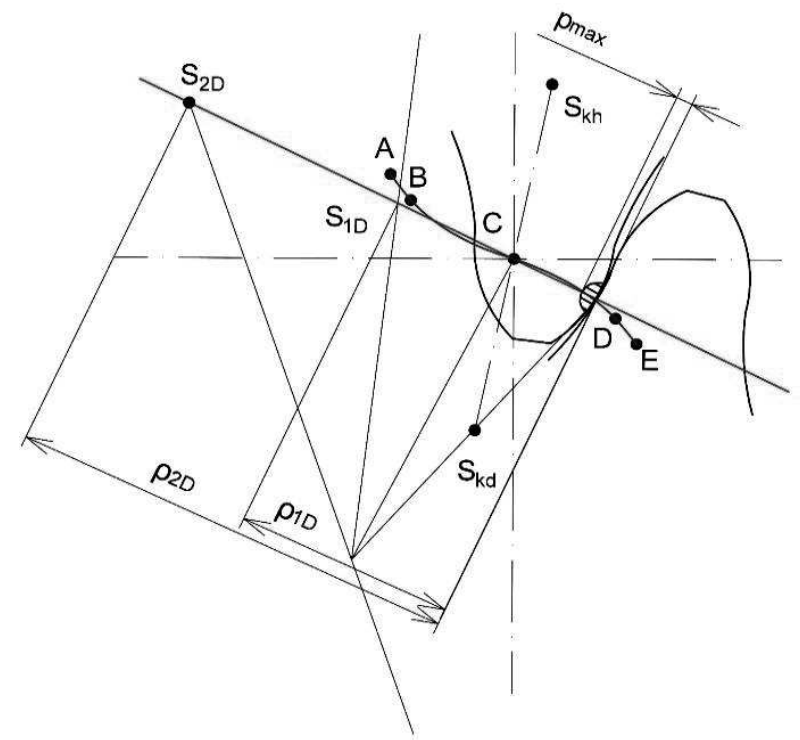

Fig. 3 Two teeth in mesh and size of contact pressure in C-C gearing 


\section{Results and discussion}

Fig.4. shows, a DLC coating is depicted. The average coating thickness was $1.2 \mu \mathrm{m}$. The presence of silicon and chromium as interlayer uder the coating is also obvious. These elements are used with DLC coatings to improve adhesion to the substrate. In Fig. 5 there are trace of scratch test. The acoustic emission signal, plotted in Fig. 6 , corresponds to the state of morphology of the scratch test damage. The acoustic emission signal pattern on DLC samples corresponds to gradual fine cracking and tearing of the coating on the scratch bottom. The process is steady and develops gradually into larger depths of the material. Delamination of the coatings was recorded approximately at a load of $50 \mathrm{~N}$, which compares to the value stated in the guidelines and is considered to be satisfactory. The friction coefficient during the scratch test is shown in Fig. 7.

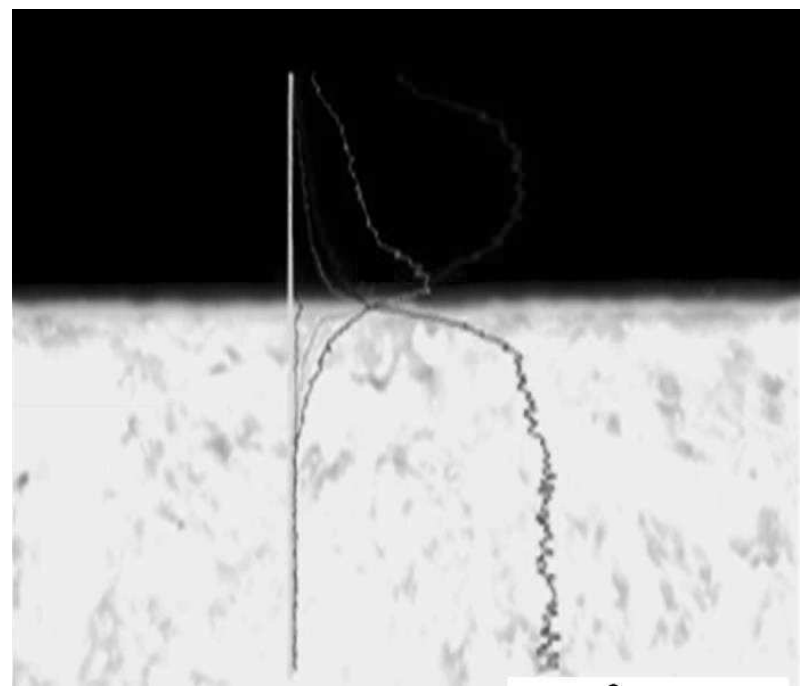

a)

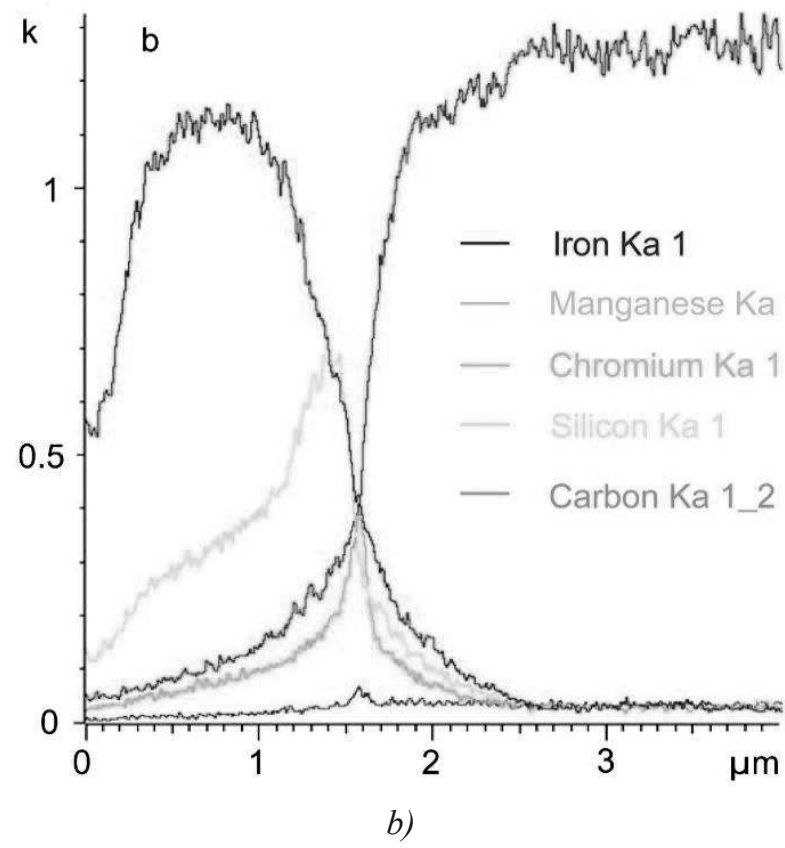

Fig. 4 Microstructure and distribution of elements in the DLC coating on C60E base materials; EDS a) DLC coating on substrate, b) layout of Elements DLC coating and substrate
The coating may peel as a result of a step change of chemical composition at the substrate-coating interface. The removal of the negative influence on the tribological characteristics due to the step change between the substrate and the coating can be achieved by chemical-thermal treatment of the surface coating. Surface hardness was determined at Berkovich indentor load values of 20 $\mathrm{mN}, 2.5 \mathrm{mN}$ and $0.5 \mathrm{mN}$. The identical nano-hardness of 4.1 GPa was measured at the highest load due to penetration of the indentation into the substrate. For this reason, Fig. 8 shows the depth of indentation at the loads of 2.5 $\mathrm{mN}$ and $0.5 \mathrm{mN}$. From Fig. 9 it is clear that when $2.5 \mathrm{mN}$ load is applied, the indenter penetrates through the DLC coating as far as the substrate (coating thickness 1200 $\mathrm{nm}$ ). Fig. 10 shows the arithmetic average of the five measurements on of the DLC coatings by loding $0,5 \mathrm{mN}$. The nano-hardness of the DLC coating was 14.4.

The friction coefficients of the coatings depending on the length of the sliding path are shown in Fig. 11. They stabilized approximately after $10 \mathrm{~m}$. The DLC coating showed a small coefficient of friction $(>0.1)$ after stabilization. The Ball on Disk friction coefficient is more versatile in terms of the way of loading the gears compared to scratch tests.

C-C convex-concave gearing is a special type of gearing, which is different in the shot from the involute gearing, since there is a reduction of touch pressure in the shot of the teeth and thus increases their load carrying capacity, Fig.3. Due to their different geometry, it is not possible to use in their manufacture standard tools for involute gearing, but special milling tools, where their accuracy is important. However, the test wheels were produced with a roughness of only about $\mathrm{Ra}=1.2$. Since for the application of hard thin coatings the surface of the tooth flanks should have a lower roughness $(0.5 \mu \mathrm{m})$, it was necessary to run of the wheel so that the roughness can be reduced to the $\mathrm{Ra}=0.6 \mu \mathrm{m}$ limit.

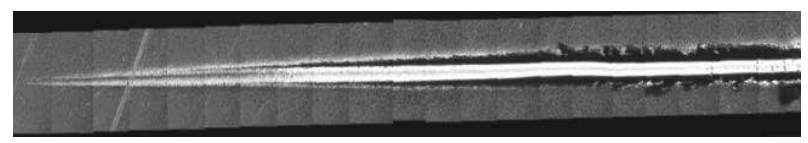

Fig. 5Traces of scratch tests on DLC coating

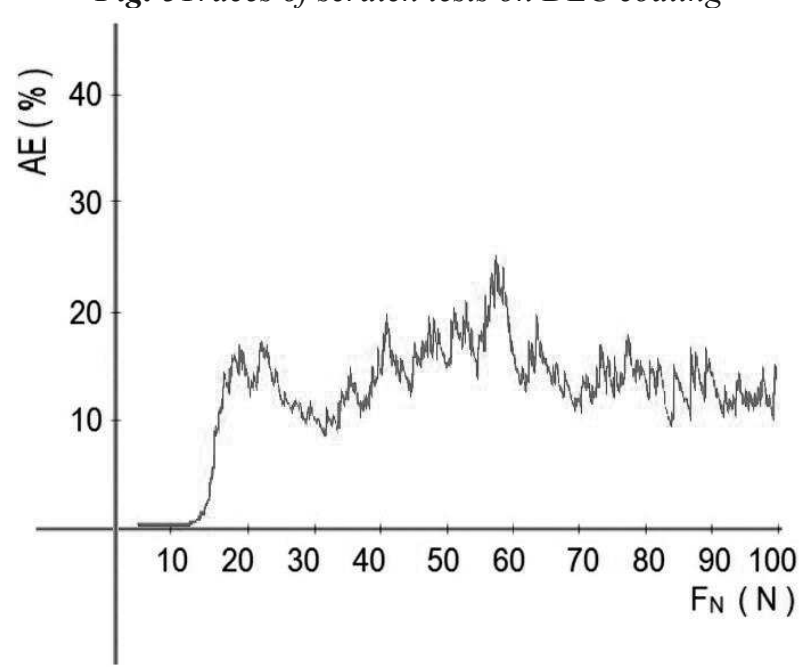

Fig. 6 The acoustic emission signal on C60E substrate with DLC coating 


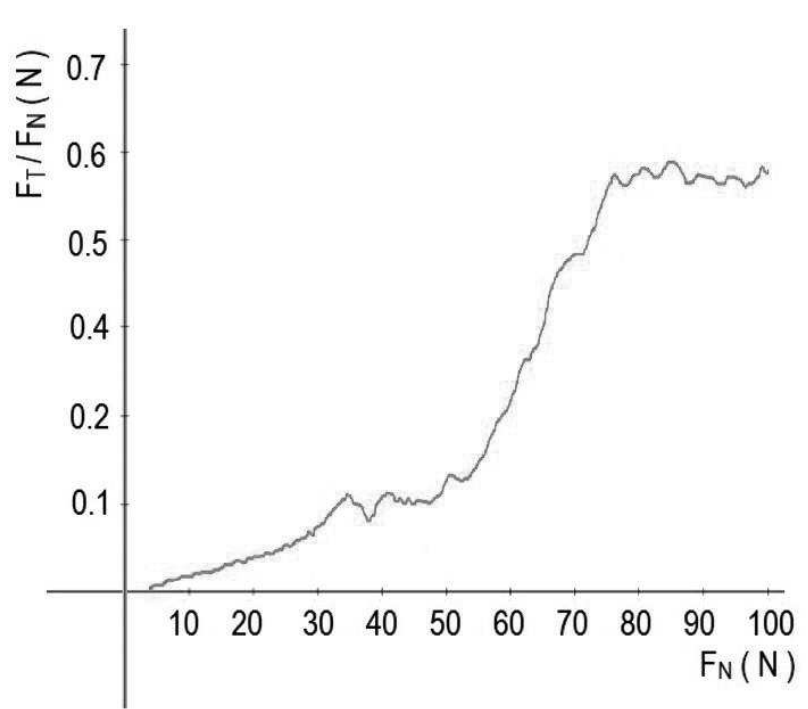

Fig. 7 Friction coefficient versus sliding distance for DLC coating

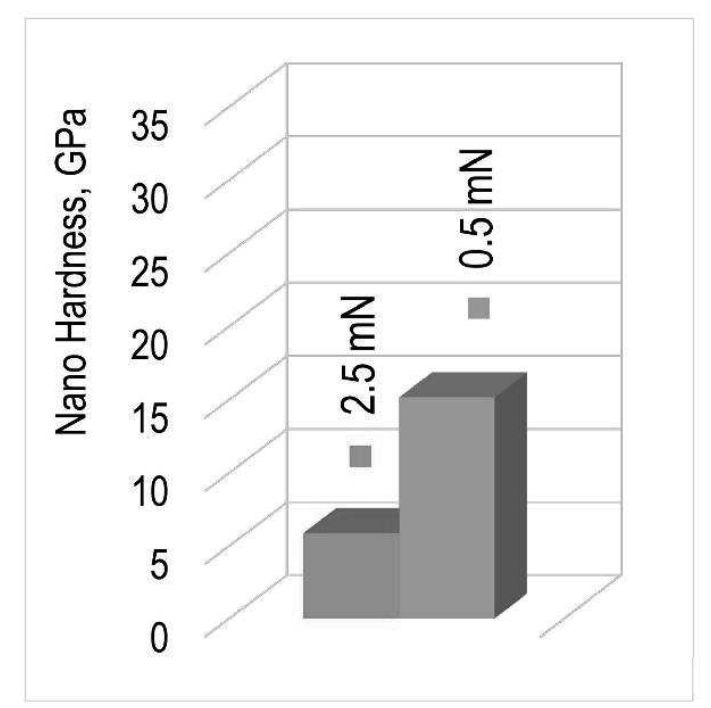

Fig. 8 Nanohardness values of DLC coating on C60E substrate at different load values

The C-C convex-concave gearing set was tested on a Niemann's tester (FZG test) [15], where the teeth are gradually loaded from 1 st to 12 th load stage. The DLC coating was worn out after the 5 th load stage. DLC coating was worn-out then the steel material was removed from the protrusions of the unevenness and then fillingup depressions, Fig. 12, where the wear surface of the non-coated tooth interface and the DLC coating is shown. DLC coating residue is at the bottom right. Vertical traces are a feature on the relief of the side of the tooth after the machining process. Horizontal strips are a sign of material removal from hard surface coating during the wear test. The complete removal of the coating was preceded by gradual thinning. After its removal, the wear continued substrate. The primarily, in the direction of load, the ma- terial under plastic deformation in the protrusions gradually filled in the irregularities on the machined surface and afterwards was substrate removal by abrasive wear. The article [17] shows the results of scuffing tests for C$\mathrm{C}$ gearing with TiCN coating on a Niemann's tester on the same substrate (C60E steel). The TiCN layer had a thickness of $3.3 \mu \mathrm{m}$, a substantially higher hardness (41.8 $\mathrm{GPa}$ ) than the DLC layer but a higher friction coefficient. Scuffing TiCN coating gearing was noted after the 7 th load level. The analysis of the results showed that the hardness and thickness of the layer are more important parameters of the bearing capacity of the layer then the friction coefficient on the gearing.

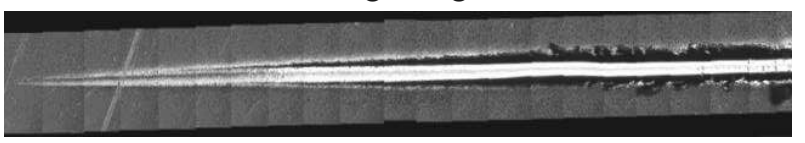

Fig. 5 Traces of scratch tests on DLC coating

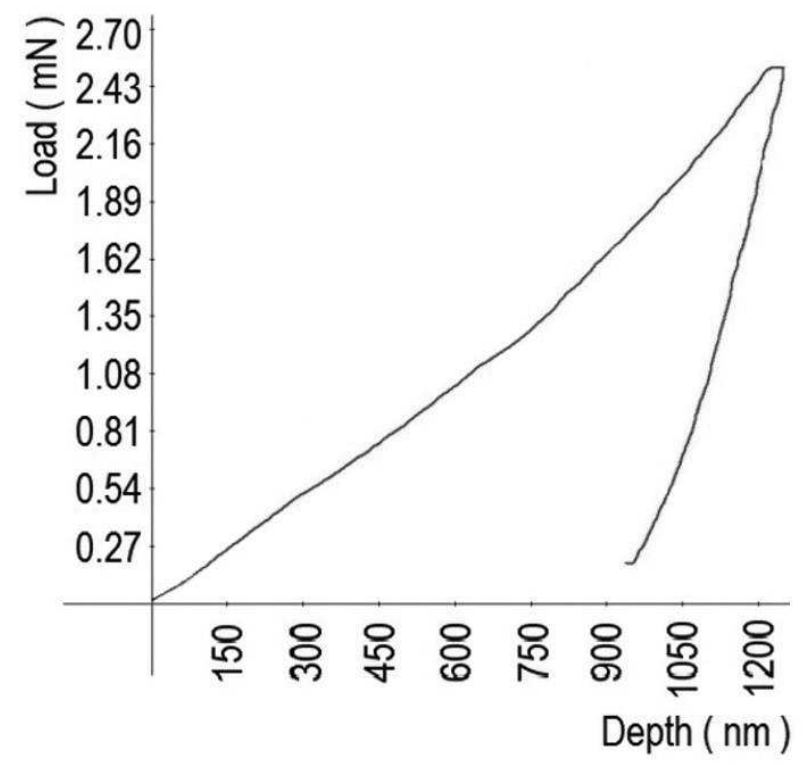

Fig. 9 Indentation curve for DLC coating on C60E substrate at a load of $2,5 \mathrm{mN}$

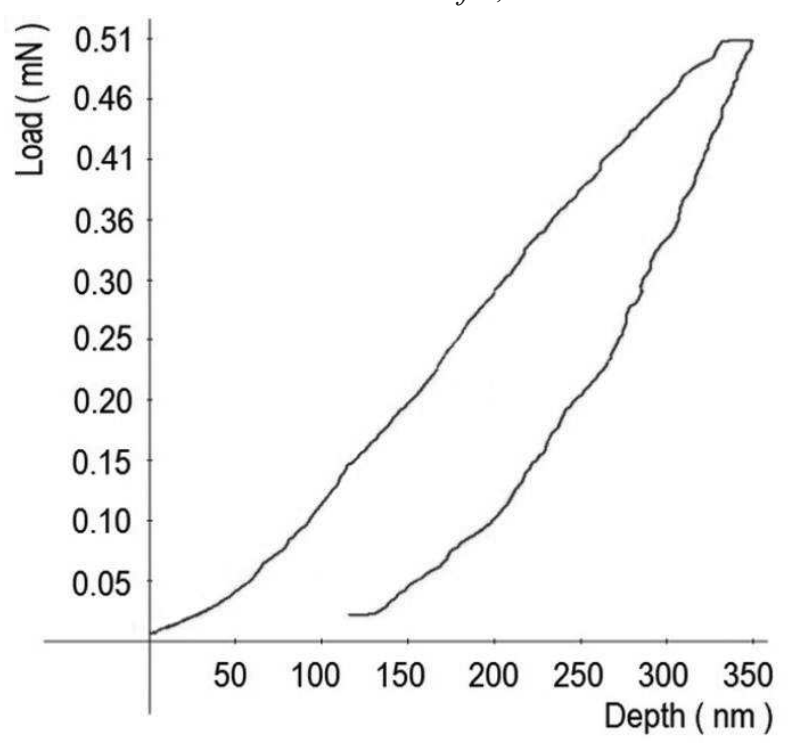

Fig. 10 Indentation curves for DLC coatings on C60E substrate at a load of $0,5 \mathrm{mN}$ 


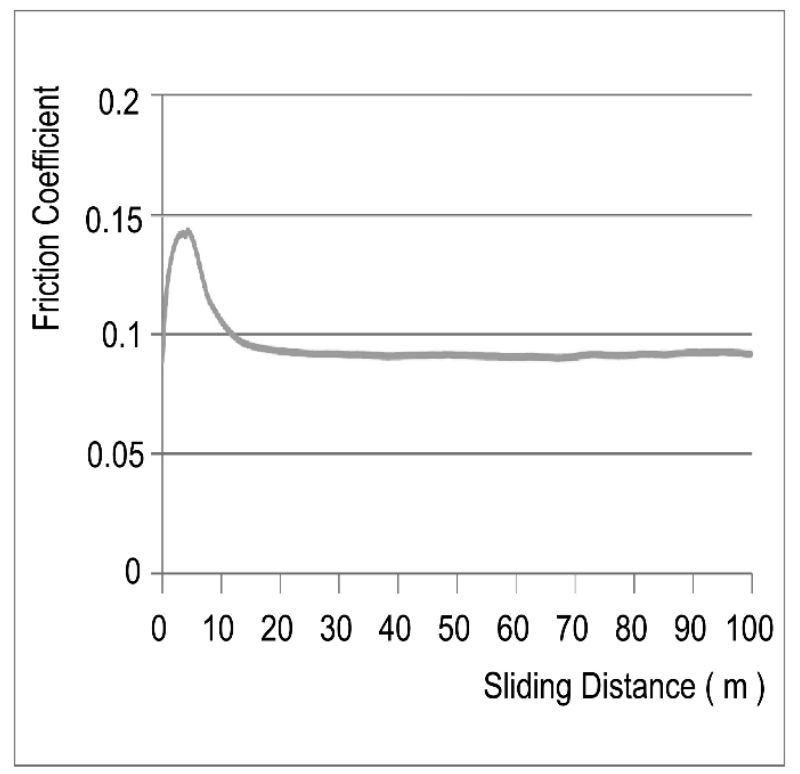

Fig. 11 Friction coefficient of DLC coatings on C60E substrate versus sliding distance

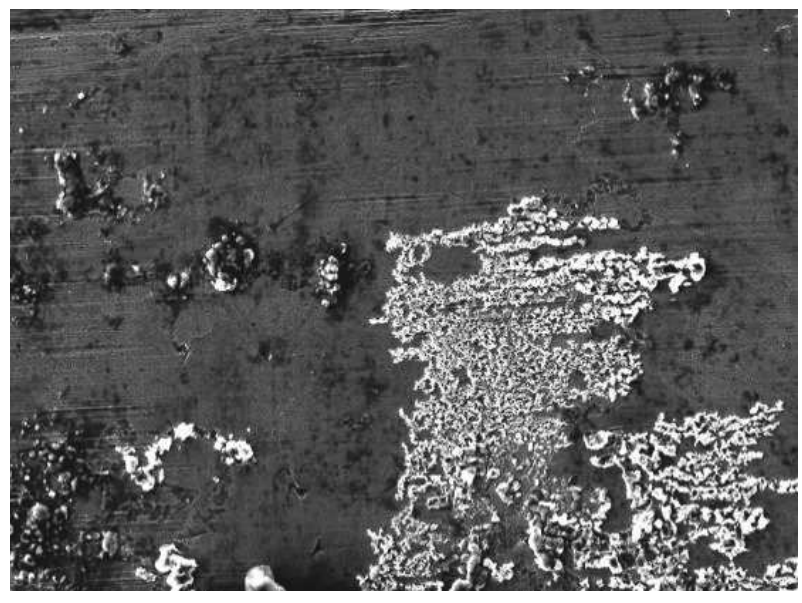

Fig. 12 Surface of worn tooth with DLC coating

\section{Conclusion}

This paper discusses the possibility of increasing the surface load capacity in $\mathrm{C} 60 \mathrm{E}$ steel gearings by applying DLC thin coating on convex-concave gearing (C-C). Tribological charakterstics, such as friction coefficient, wear, adhesion and hardness of DLC coating were measured by scratch test a method ball on disc. The average thickness of DLC coating is $1.2 \mu \mathrm{m}$. Delamination of the DLC coating was recorded at a load of approximately 50 $\mathrm{N}$. The friction coefficient of the DLC coating was 0,09 . The nano-hardness of the DLC coating was $14.6 \mathrm{GPa}$.

The results of the scuffing tests $\mathrm{C}-\mathrm{C}$ gearings on the Niemann's tester show that the DLC coating deposition occurred at load level 5.

The lower specific slip, contact pressure and the application of the chosen type of oil in $\mathrm{C}-\mathrm{C}$ gearing allows the use of coatings with a higher friction coefficient compared to involute gearing. The further increase of loadbearing capacity can be achieved by applying a multilayer coatings where the top layer has a low coefficient of friction. An example of such a layer is also a DLC coating.

\section{Acknowledgements}

This work was supported by the Grant Agency of the Ministry of Education of the Slovak Republic within the project VEGA 1/0394/16 Study of the possibilities of preparation and application of composite materials from waste wood and plastics and the project $V E G A$ 1/0227/15 Study of tribological characteristics of the new high hardness coatings on the materials suitable for gearings and with the support of the University Research Park STU Bratislava, ITMS 26240220084

\section{References}

[1] BOŠANSKÝ, M., VEREŠ, M., TOKOLY, P., VANYA, A. (2012). Neštandardné ozubené prevody, STU Bratislava 2012, ISBN 978-80-2273713-5

[2] BOŠANSKÝ, M., OROKOCKÝ, R., JANČEK, R. (2015). Possibilities of using AutoCAD to design new teeth profiles.In: Visnik Nacionalonovo-techničeskovo Universiteta Charkov, 2015,Vol. 1143, No. 34, p. 15-19, ISSN 20790791

[3] VEREŠ, M., BOŠANSKÝ, M., GADUŠ, J. (2006). Theory of Convex-Concave and Plane Cylindrical Gearing. Vydavatel'stvo STU Bratislava 2006, 180p., ISBN 80-227-2451-3

[4] RUSNÁK, J. (2005). Štúdium tribologických vlastnosti materiálov nanesených na povrch nekonvenčnými technológiami. SPU Nitra, 2005, ISBN 80-8069-485-0

[5] NOWAK, D., JANUSZEWICZ, B., NIEDZIELSKI, P.(2017). Morphology, mechanical and tribological properties of hybrid carbon coating fabricated by Radio Frequency Plasma Assisted Chemical Vapor Deposition. In: Surface and Coatings Technology, Vol. 329, 2017, p. 1-10, ISSN 0257-8972

[6] HONGBO JU, XIAOCHEN HE, LIHUA YU, JUNHUA XU. (2017). The microstructure and tribological properties at elevated temperatures of tungsten silicon nitride films. In:Surface and Coatings Technology, Vol.326, Part A, 2017,p. 255, ISSN 0257-8972

[7] KUSMIC,D., DOAN, T., V., HRUBY, V. (2018). Corrosion and Wear Resistance of Plasma Nitrided and Duplex Treated42CrMo4 Steel. In: Manufacturing Technology, Vol. 18, Year 2018 p. 259-265, ISSN 1213-2489

[8] YANG LI, YONGYONG HE, JUNJIE XIU, WEI WANG, YIJIE ZHU, BAOGUO HU. (2017). Wear and corrosion properties of AISI 420 martensitic stainless steel treated by active screen plasma nitriding. In: Surface and Coatings Technology, Vol.329, 2017,p. 184-192, ISSN 02578972 
[9] VANYA, A. (2012): Návrh štruktúry deponovanej vrstvy ako systému „Povlak bok zuba“ z hladiska požiadaviek vybraného ozubeného prevodu, Dissertation, STU Bratislava 2012

[10] CONSTANTINOU, M., PERVOLARAKI, M., KOUTSOKERAS, L., PROUSKAS, C., PATSALAS, P., KELIRES, P., GIAPINTZAKIS, J., CONSTANTINIDES G. (2017): Enhancing the nanoscratch resistance of pulsed laser deposited DLC films through molybdenum-doping. In: Surface and Coatings Technology, Vol.330, 2017, p. 185-195, ISSN 0257-8972

[11] DOBRODCKY, D., POKORNY, Z., STUDENY, Z., DOAN, T.,V. (2018). Analyse of Tribological Propeties of Layers Created by Plasma Nitriding+DLC In: Manufacturing Technology, Vol. 18, Year 2018 p. 379-386, ISSN 1213-2489

[12] KABIR,M.,S., MUNROE, P., ZHIFENG ZHOU, ZONGHAN XIE. (2017). Scratch adhesion and tribo ogical behaviour of graded $\mathrm{Cr} / \mathrm{CrN} / \mathrm{CrTiN}$ coatings synthesized by closed-field unbalanced magnetron sputtering In:Wear, Vol. 380-381, 2017, p. 163-175, ISSN 0043-1648

[13] MÍŠANÝ, J.(2015). Vplyv prevodového ústrojenstva stavebného stroja a možnosti zvýšenia jeho únosnosti so zameraním na zniženie ekologického zat’aženia pôdy. Dissertation, SjF STU Bratislava, 2015

[14] ŠRAMHAUSER， K., KUSMIERCZAK, S. (2016). Laser Hardening of the Functional Surfaces of Machine Tools. In: Manufacturing Technology, Vol. 16, Year 2016 p. 248-253, ISSN 1213-2489

[15] FZG Test, ISO 14635-1:2000

[16] RUSNAK, J., KADNAR, M., KUČERA, M.(2009). Biologicky odbúratel'né oleje. SPU Nitra, 2009, ISBN 978-80-552-0166-5

[17] GONDAR, E., BOŠANSKÝ, M., REPKOVA, J., TÓTH, F.(2018). The Carrying Capacity of TiCN Coatings on Convex-Concave (C-C) Gearings. In: Modern Machinery (MM) Science Journal, Vol. 12. ISSN 18050476 